\title{
Narrative Mode: A comparative Study on Selected Short Stories of Leo Tolstoy and Edgar Allan Poe
}

\author{
Liknaw Yirsaw ${ }^{1, *}$ \\ ${ }^{1}$ English Language and Literature Department, Debre Markos University, Debre Markos, Ethiopia \\ *Correspondence: English Language and Literature Department, Debre Markos University, Debre Markos, Ethiopia. \\ E-mail: yilkalyirsie@gmail.com
}

Received: August 12, 2016

Accepted: August 29, 2016 Online Published: September 24, 2016

doi:10.5430/wjel.v6n3p24

URL: http://dx.doi.org/10.5430/wjel.v6n3p24

\begin{abstract}
Narrative mode is the way in which narrators designed to present the intended story in narratives. narrative mode is therefore the very important issue that should be studied for it is through their narrative mode or way of narration of the narrator that writers can do an effort in the reading process of readers in literature or work of art, and it is due to this reason that scholars like Ronald Barthes' idea of 'death of the author' believe the writer has not a power to say 'the reader should do and shouldn't do like this and that' after his/her writing is over. Thus, narratives ingeneral and narrative mode should be taken as a central point in the investigation of narrative strategies; since other aspects of narration like voice, focalization, narrative time and etc would be included in the discussion of narrative mode as a way of narration. Therefore, this study discusses narration in one organized work of study for narrative mode has a tendency to include almost all elements of narration or narratology for narratology is the study of narration and narrative mode is all about ways/techniques of narration in narrative strategies. All in all, the very intention behind this research is related to bring one window of consideration on the different types of narrators and narrative modeshow the narrative is intrusive or extrusive to the story. In other words, if we consider all the criteria tried to be used by the different scholars in the classification of narrators that different scholars classify differently, we can subsumed into one paradigm-related with narrators' extrusiveness or intrusiveness to the narrative story they narrate. Therefore, our narrative mode that we can experience in literary texts would be either 'telling mode or showing mode', the direct or indirect mode or the diegesis or mimesis mode of narrative. Regarding to the literary products underdiscussion; some short stories of Tolstoy and Poe; both these two authors are very famous and well recognized personalities in the Easter/Russia and Western/America part of the world respectively.
\end{abstract}

Keywords: narrative mode; telling mode; showing mode; tolstoy; poe; diegesis; mimesis

\section{Introduction}

\subsection{Background}

As it has been indicated in the abstract part of this article, Narrative mode is believed to be the way through which narrative is made. In other words it is the way in which writers bring the story into the minds of readers through narrators as the agent of narrative Bale (1997). Therefore, narrative mode is the way in which narrators designed to present the intended story in narrative discourse.

Narrative discourse has six components. Scholars suggested narrative discourse has the following components both in the text and outside of the text. For example in Leech and Short (1981), we can get the author (the one who wrote the text), the implied (author, the paper being of the real author), the narrator (the one who tells the story), the narratee (the one who is addressed by the narrator), the implied reader (the representative of the actual reader-the paper being of the reader) and the reader.

From the above elements only the writer and the reader are out of the text; whereas, the rests are in the text. Therefore narrative mode, the craft of telling the story through narrators is the way of inculcating these four inside components of the narrative discourse. In short, narrative mode is the concern of creating narrators; it is through narrators that the writer can draft the narratee and the implied author intransitively. Therefore, narrators are the focal 
points in the study of narrative mode, and scholars categorize narrators in different ways based on their own criterion. The two criteria that Gentte (1980) used to classify narrators are 'the narrative level that the characters belong' and 'the extent of their participation to the story they narrate'. We can have diegetic, intra-diegetic, hypo-diegetic and hypohypo-diegetic narrators as first, second, third and fourth degree narrators based on their level of belongingness. When we take the second criterion-their extent of participation in the story narrated, we can have hetero-diegetic and homo-diegetic narrators.

As Remmon Kenan (1983), we can have reliable and unreliable characters. Plus, as Chatman (1978), we can have cover and over narrators as categories of narrators. If we consider all the criteria tried to be used by the different scholars in the classification of characters above, we can subsumed into one paradigm-related with narrators' extrusiveness or intrusiveness to the narrative story they narrate. Therefore, our narrative mode that we can experience in literary texts would be either 'telling mode or showing mode', the direct or indirect mode or the diegesis or mimesis mode of narrative which or narrative is the point of discussion of the current study.

\subsection{Statement of the Problem}

As it has been indicated in the background part of this study, classifying the narrator inparticular and the narrative mode ingeneral in different categories is not systematic, and it is tiresome for it doesn't provide any earnings in the study of narration. Regardless the different criteria used in the classification or categorization, the very important issue here is how the narrative strategy/ narrative mode is intrusive or extrusive to the narrative story; and it is the concept that brings the different categories of narrator or narrative modes into one category or paradigm as be either 'telling mode or showing mode', the direct or indirect mode or the diegesis or mimesis mode of narrative. It is less important to categorize narrators and narrative strategies/modes than to identify the features that mark their degree of audibility. A quantitative effect applies; the more identifying features the stronger our sense of narrator's presence. The 'none' or minimally narrated story is simply one in which no or very few such features occur (Chatman, 1978: 196).

Therefore, as it is depicted in the extract above, the different narrative strategies or narrators (hetero-diegetic, homo-diegetic, authorial, figural, cover, overt, so on) can come into one category-inclined to the less presence and the more presence of the narrator, the showing mode and the telling mode of narrative strategy; and this is in a continuum. In other words, we couldn't have a clear demarcation in the leveling of showing and telling narrative mode. It is through the signals which indicate us the more and less involvement of the narrator in the narration process that we could sense the showing and telling modes of narration are in a continuum.

Plus, narrative mode is therefore the very important issue that should be studied for it is through their narrative mode or way of narration of the narrator that writers can do an effort in the reading process of readers in literature or work of art, and it is due to this reason that scholars like Ronald Barthes' idea of 'death of the author' believe the writer has not a power to say 'the reader should do and shouldn't do like this and that' after his/her writing is over. Thus, narrative ingeneral and narrative mode /way/ technique of narration should be taken as a central point in the investigation of narrative; since other aspects of narration like voice, focalization, narrative time and etc would be included in the discussion of narrative mode as a way of narration. Hence, as it has been indicated above, the point of discussion in this study is inclined to be a discussion on 'Narrative Mode on some Leo Tolstoy's and Edgar Allan Poe's Short.

The additional intention which led the research to study this study/a discussion on narrative mode is to discuss narration in one organized work of study for narrative mode has a tendency to include almost all elements of narration or narratology for narratology is the study of narration and narrative mode is all about ways/techniques of narration in narrative strategies. Plus, narratology is a recently inaugurated concept in the study of literature, thus, narratological elements like narrative mode is the issue which needs further investigations.

When we come to the literary products underdiscussion; some short stories of Tolstoy and Poe; both these two authors are very famous and well recognized personalities in the Easter/Russia and Western/America part of the world respectively; and this paper is intended to address the following research questions.

$>$ Is there a significant difference in the different types of narrators supposed to be the mouthpiece of the narration process?

$>$ Is there universally accepted narrative mode/technique used to narrate a certain issue/content?

$>$ What are the signals used to identify the narrative mode employed in a certain text? 


\subsection{Objective of the Study}

\subsubsection{General Objective}

The main objective of this study is to show the different categories of narration/narrative mode come into one paradigm- the narrative mode/narrator is intrusive or extrusive to the story, narrated in the narration process.

\subsubsection{Specific Objectives}

We can possibly deal the following issues by deducing ideas from the general objectives, stated above as the specific or minor objectives of the study.

The question of appropriateness: this is the issue related to identify the kind of narrative mode/telling or showing is convenient to a certain situation or area.

The kind of relationship between and/among the different categories of narrative modes, like the authorial/figural, the homo-diegetic/hetero-diegetic, first-person/third-person, etc mode narrative.

The expressions, texts or signals which enable us to identify the narrative mode in the narration process of texts.

\section{Preliminary Review and Conceptual Framework}

This part of the paper tries to make an attempt to organize issues on the related literature and the theoretical framework on narrative mode and its related issues, like the very essence of narrative modes, the different modes/paradigms of narrative, narrators, thought and speech representation and etc.

\subsection{Preliminary Review of Related Literature}

M.Mitchell and M Edugo (2003) came to a conclusion, narrative skill or technique is the skill which includes issue like relationship between among personal stories, culture, and political forces in which life stories do not simply reflect actual events but actively shape who an individual is.

Michael Bamberg (2010). Narrative Analysis Narrative inquiry that is more interested in how meaning is conferred onto experience, especially in narratives of personal experience about concrete life situations (starting from experiences such as menarche or first romantic involvements to larger research questions such as divorce, professional identity--all the way up to aging and life satisfaction) has traditionally leaned more toward the employment of qualitative research procedures.

Jan Christopher Meister. (2013) came to a conclusion as Narrative Mode as is dedicated to the study of the logic, principles, and practices of narrative representation. Therefore narrative mode mat be taken as everything in narratology.

Julia Chaitin. (2003), the study on the technique of storytelling /narration/narrative mode came with a conclusion that narrative mode is always there as narrative is there; People are storytellers they tell narratives about their experiences and the meanings that these experiences have for their lives. All cultures and societies also possess their own stories or narratives about their past and their present, and sometimes about their view of the future. These narratives include stories of greatness and heroism, or stories of periods characterized by victimhood and suffering.

Demeke Tassew. (2014) is a paper coming to an end with the conclusion that it is the way narrative forms are constructed motivates the textual and contextual meaning of the text. Alem (2011) MA thesis on narrative mode on selected Aimattadoo's short stories came with the conclusion that the narration on the short stories underdiscussion is provided in most cases with telling mod of narration. In addition the MA thesis made by Melkie (2011) on narrative mode on Achebe's novel, A man of the People came with the conclusion that the narration process of the novel is influenced with telling the contrasting effects of the two/ new and old generations of West Africa.

\subsection{Conceptual Framework}

\subsubsection{Narrative Mode}

Narrative inquiry is increasingly being used across disciplines in the human sciences to investigate a multitude of questions... Narrative inquiry has increasingly gained popularity among researchers and academicians in the last several decades. It is utilized across academic disciplines and professions, Riessman (2008). From this we can understand that narrative mode is there every disciplines and as old as human life as narration have been experienced. In other words, narrative is not a recent phenomenon though its scientific study-has been inaugurated recently. Therefore, narrative mode was (is) there as human life came to be both in Literature and other fields and in any life engagements. Narrative is all around us not in the novels or in historical writings (Fludernik, 2009: 12). 
Therefore, narrative mode is an intentional technique of storytelling; Narratives are intentional communication artifacts; intentionally fashioned devices of representation that works by manifesting the communicative intentions of their markers. The representational content of a narrative is the story it has to tell, and we can provide a notion of representational content which fits both fictional and nonfictional narratives (Currie, 2010: 17). This intentional storytelling is achieved through creating narrators/story tellers as the agent of the writer based on his/her choice of narration; and it is good to review concepts on narrators as narrators are the focal points in the discussion of narrative mode.

\subsubsection{Narrator}

A narrator is someone or a person that tells or represents the story to the audience (Chatman, 1978; 34). A narrator is the person or an agent of someone in a narrative fiction whose account of a story is presented or happened in an imaginary world (Jahn, 2005: N2.2.2).

Therefore, a narrator in narrative mode is an element of narrative communication, crafted by the write of an imaginative work, and it is the one who is participating in rendering a story of a narrative discourse. Narrators in narration are expected to be responsible to his/her identity, degree and manner. These three concepts, identity, degree and manner are use in narrative modes to show the 'intrusiveness' and 'extrusiness' of the narrator; in turn, this shows us whether the narration is experienced in showing or telling mode of narration.

Scholars contradicted in their assumption about the presence of narrators in narrative communication. There may/may not be a narrator-narratee relationship in narrative Chatman (1978). However;

In my view, there is always teller in the tale, at least in the sense that any utterance or record of an utterance presupposes who has uttered it. Even, when a narrative text presents a passage of pure dialogue, manuscript found in a bottle, or forgotten letter and diaries, there is in addition to the speakers, or the writers of this discourse a 'higher' narratorial authority responsible for 'quoting' the dialogue or 'transcribing' the written records( Remon-Kenan, 1983: 88).

Here, she believes that the notion of narrator-narratee relationship is not optional; it can be minimally defined as the agent which at the very least the narrator may engage. In other words, she argues the narrator may hide/covertly reveal her/himself, but the narrator is not totally absent in the narration process. This notion of covertly intermediating tells us that it is impossible to enter in the hearts and minds of characters with no intermediacy of the narrator in any mode of narration.

The in-experience reader may make the mistake of thinking that the story comes to him unmediated. But no such mistake can be made from the movement that the author explicitly places a narrator into the tale, even if he is given no personal characteristics whatever (Booth, 1982:153).

In addition, another strongly argues the unavoidable nature of a narrator in a narrative text. In 1954, Wolfgang Kayser warned that if lose of sight of that the narrator is 'someone' who tells a story, the novel is dead: 'the death of the narrator is the death of the novel' (quoted in Richardson, 2006: 1). So, here one should consider that though there is not a clearly observable distinction between the author and the narrator in some showing narrative narration, there is always a narrator as the text is there. From this we can say that whatever the narrator is hidden which couldn't easily or distinctively be identified by the reader, there is always a narrator as a certain text is there in the narration process.

In addition to narrator, 'point of view and its relation to narrative mode' is a very important issue that should be discussed in the discussion of narrative mode as a technique of narration.

\subsubsection{Point of View and Its Relation to Narrative Mode}

Chatman (1978) states that point of view may be seen from someone's eyes (perception), from someone's worldview (ideology and conceptual system), and from someone's interest (vantage) termed literal, figurative and general interest respectively. The crucial difference between point of view and narrative voice is that point of view is the physical place or ideological situation practical life orientations to which narrative events stand inrelation, narrative voice, on the contrary refers to the speech or other overt means through which events and existents are communicated to the audience. Point of view doesn't mean expression; it only means the perspective interms of which expression is made (Ibid: 153)

Therefore, it is possible to say point of view is the perspective from which meaning is made through the voice we hear. So who is directly communicating with the reader is the voice, and from what position or angle the story is told or what channels of information the narrator tries to convey about the character is the point of view. 
To sum up both point of view and narrative have implications to the narrative mode that writers choose to show which voice of narration should be heard to what stand of understanding/view point is conveyed. Mostly, in showing mode of narration narrative voice and point of view may be overlapped for the narrator tries to take us into the minds and hearts of characters so that we are coming to the view points of characters; on the contrary voice and point of view have a relatively identified gaps in telling mode of narration for the great involvement of the narrator is there in telling mode of narration; hence, we are supposed to hear the voice of the narrator and experience the vantage point of the character for the story is expected to be all about the character. It is due to this reason that point of view and voice are considered to be point of arguments in the narrative mode of narration.

\subsubsection{Speech and Thought Representation}

It is known that speech and thought representation is the mechanism through which writers bring characters into life as human agents. The representation of speech and thought is mostly related with point of view, tone and distance of the narrator. Based on these elements, point of view, tone and distance, we can categorize speech and thought representation in forms of gradation from scenic/showing mode of narration to telling mode of narration as free-direct speech, direct speech, free-indirect speech and indirect speech, and the same is true for the thought counterparts of these speech acts.

According to Leech and Short (1981), except some categories, available to the writer in representing his/her characters' speeches are the same as to represent characters' thoughts and distinguished in similar ways. So, what are these speech and thought categories and who are the distinguished one from the rests?

\subsubsection{Categories of Speech Representations}

The following list of speech representation category is arranged based on their level of distance of the narrator- from the most showing to telling mode of narration. In other words the presence of the narrator is increased as we move from one to the next list.

Free-direct speech (FDS) is a category of speech representation which is the untagged form of direct speech. Direct speech (DS) is the exact or direct utterance of characters. It is due to this reason that the author/narrator presents the speech to us with quotation marks (") to reveal the utterances are the characters' own words. Free-indirect speech (FIS) is the category of speech representation between direct and indirect speech representations. It is different from direct speech in a backshift of the tense because of its nature of indirectness, and it is different from direct speech because of its lack of introductory reporting clause. The last type of speech representation category is indirect speech (IS), and it is presented the characters discourse in narrator's words by shifting one stage back in the tense and shift of pronouns with the utilization of introductory reporting clause; this is the speech representation category in which telling mode is experienced than the rest of the speech representation categories.

\subsubsection{Categories of Thought Representation}

Leech and Short (1981) suggests that it was speech representation that received priority than thought representation in novelist expressions. In other words speech representation had got attention before thought representation. However, in the twentieth century, the idea of thought representation has got inaugurated, and now it is a common practice. Basically, thoughts are the basic foundations of speeches for speeches should be thought before they are verbally produced.

Except some exceptional, the categories of thought representations are similar with their speech counterparts. When we see the exceptional, the distance of the narrator from the thoughts and speeches of characters, the distance of the narrator in free-direct speech and its thought counterpart is not similar. In the case of free-indirect thought we are not nearer to the character's mind than free-indirect speech. The issue will be clear when we consider the base-line or the norm. It is the concept which implies the narrator's presentation of the direct or exact thoughts and speeches of characters. This norm is different in the case of indirect speech and its thought counterpart. Direct speech is taken the baseline in speech representation; whereas, it is not the direct thought, rather it is the indirect thought taken as the norm or baseline. Because, scholars argue that it is impossible to know what characters exactly think; thus narrator's intermediacy in thought representation is unavoidable. The direct perception of someone's thought is not possible, direct thought is perceived as more artificial than indirect forms. When DT is used, the writer is the effect saying, this is what the character would have said if he had made his thought explicit. It is this explicitness which gives rise to the conscious qualities of DT and FDT (Leech and Short, 1981: 345).

All in all, except the above explained issues, the categories available to the writer in representing the thoughts of his/her characters are similar to what he/she uses to represent the speeches of characters. Therefore, we can have 
free-direct thought, direct thought, free-indirect thought and indirect thought as their categories of speech representation counterparts are there.

There are ideas like 'stream of consciousness' and 'psycho narration' raised inrelation to thought and speech representation especially with thought representation. Stream of consciousness has been originated by known American psychologist, William James Chatman (1978), Leech and Short (1981), Short (1996), Jahn (2005), toolan (2001). These experts suggest that stream of consciousness is mostly related with interior monologue or internal monologue, and it is broader than interior monologue; they defined 'stream of consciousness' as I the random ordering of thoughts and impressions in characters' minds'. Similarly, Jahn (2005) states 'psycho narration' is the textual representation of the characters' conscious or unconscious mental states through narrative report of discourse or narrative perception. Narrative report of discourse is the narrator's skill of rendering the characters' speech and thought in his/her own words, and narrative perception is the textual representation of the characters' perception mainly by psycho narration, indirect discourse and free-indirect discourse Chatman (1978), Leech and Short (1981), Short (1996).

In addition to stream of consciousness and psycho narration, mind style is the concept that should be treated inrelation to speech and thought representation. Leech and Short (1981) states mind style is one's typical mode of perception or patterns of thinking, or in simple terms, is one's mindset or one's world view. We can clearly identify the character's mind style if we are exposed with the point of view of the characters; plus, the character's point of view may be represented by the mind style of the character or by the mind style of the narrator of the narrative discourse. In the first case the narrator presents us with the direct thoughts and speeches of the character so that we are nearer to the character, and it is considered as a showing mode of narrative. However, the second case takes us to a telling mode of narration, because the characters point of view is perceived from the mindset of the narrator as it is an overt narrator since its involvement in the narration process is high.

Moreover, the interrelation of point of view and speech and thought representation inrelation to the identification of the narrator under the notion of narrative mode, there are signals that we need to consider to level the type/nature of narrative mode employed in the narration process of a narrative discourse. Chatman (1978) lists signals which show us the feature of a telling mode of narration in which the narrator is overtly involved. Here is the list in ascending order from the least telling to highest telling mode of narrative; description of setting, identification of characters, temporal summary, definition of characters, reporting what the characters did not say or think and commentary-interpretation, judgment and generalization.

Description of setting is one of the signals the presence of the narrator/telling mode of narration, and it is the weakest marker of telling narrative mod, even we can get description of setting in less narrated stories. The important point here is considering from what point of view description is made. So, the narration would be a signal for telling mode when the description is made from the narrator's point of view, but if the description is made from the point of view of the character, the narrative mode is not a telling mode; rather, it is a showing mode of narration.

The identification of the character is another indicator/signal of telling mode; because, in most cases identification of characters is made with the narrator's prior experience or acquaintance with the character of the story so that the narrator is nearer to the narration process. Temporal summary or summary of a synopsis of a single incident in the story line which is made as result of the narrator's intention to answer the reader's answer in each interval of the story-line is an additional signal of telling mode of narration.

Plus, definition of characters, introducing characters to the audience by the narrator is again another signal of telling mode of the story. Moreover, telling mode of narration is related with narrator's report of what the character doesn't say /think. It is natural that the character is unable to think or say every aspect of narration. In this case the narrator is supposed to show not only the character says/thinks; but also, what the character doesn't say/think in the narration process.

The last and highest indicator is telling mode is the narrator's skill of providing commentary including in interpretation, judgment and generalization.

Commentary is either implicit (ironic) or explicit. The later includes interpretation, judgment, generalization and self conscious narration. Among these explicit comments, the first three are upon the story. Interpretation is the open explanation of the gist, the relevance and the significance of the story elements. Judgment expresses the moral or other value opinions. Generalization makes reference outward from the fictional to the real world either to universal truths or actual historical facts. Self conscious narration is a recently coined term used to refer comments on the discourse rather than the story (Chatman, 1978: 228). 
So far, we have seen the some of the signals which indicate telling mode of narration where any element of narration whose point of emphasis is from the narrators point of view in the narration process; whereas, any mode of narration presented from the character's point of view where the narrator's involvement is out of the story line is considered a showing mode of narration.

\section{Method of the Study/ Theoretical Framework}

Here the research is a qualitative study; thus, the study is carried out the textual analysis method which focuses on the descriptive and critical textual analysis of the short stories under discussion inrelation to the narrative mode, employed in the narrative process as a technical issue of considerations. In other words, the technique issue/narrative mode is investigated through content or textual issue treated in the text as technique and content are inseparable aspects in literary works as the two sides of a coin.

This investigation is carried out based on the theoretical framework that Chatman (1978), Remmon Kenan (1983) and Leech and Short (1981) used to identify the highly or less involvement of the narrator in the identification of the narrative mode employed in literary texts either in a showing or telling mode of narration based on the signals which show the authorial involvement in the narration mode, point of view and speech and though representation.

To do so, as it has been indicated in the conceptual framework part of this paper in chapter two, Chatman and the other aforementioned scholars listed five textual clues or signals which indicate the presence of the narrator in the narration process; in turn, this implies us the telling mode of narration in ascending order from the least presence to the highest presence of the narrator as: description of setting, identification of characters, temporal summary, definition of characters, reporting what the characters did not say or think and commentary-interpretation, judgment and generalization.

Coupled with these signals, the issue of point of view and speech and thought representation will be considered in the analysis process of the short stories of the point of discussion. Because it is the point of view either the point of view of the narrator or of the character determines either the narrative mode is showing or telling. If any narration is made from the point of view of the character, the narrative mode employed is showing; whereas, if the narration is made from the point of view of the narrator, the narrative mode is inclined to be telling mode of narration.

Likewise, it is through the representation of characters' speech and thought that the narrator can make the narration. As Leech and Short (1981) If the character presents the direct speeches and thoughts of characters without any authorial involvement, the narrative mode employed is inclined to be scenic/showing mode of narration as we readers are taken nearer to the minds and hearts of characters. On the contrary, if the narrator presents the speeches and thoughts of characters through the authorial involvement, the narrative mode used to make narration is inclined to be a telling mode of narration.

For having as sample analysis to show how the analysis of the study that I am going to carry out, I have randomly selected two short stories from the two representative selected authors. I have selected "God Sees the Truth, but Waits from Tolstoy" and "The Tell- Tale Heart" from Poe. Plus I have tried to categorize each short story both in the showing and telling mode of narration in the analysis part of this paper. I.e. both the showing and telling mode of the narration in each short story is treated independently, and these short stories are attached in the appendixes.

\section{Sample Analysis}

An endeavor has been attempted to give the theoretical concepts for narrative mode in fictional works. Now there will be an attempt to deal the sample analysis in line with the theoretical concepts mentioned so far on the short stories selected to be analyzed.

Scholars believe that certainty is not absolute in the analysis and interpretation of literary products because of the difference in sensing the various features/elements by readers differently.

When a narrative situation of a passage clearly proves to be authorial or figural, the imaginative process in the individual reader encompasses by in the individual reader is by no means fixed with absolute certainty. A reader's sensitivity will depend on his ability to see a given narrative element as characteristic of report like narration or of scenic presentation (Stanzel, 1971: 29).

However, thanks to the ideas of the different scholars mentioned in the conceptual and theoretical framework as well, it is possible to minimize the problem of certainty mentioned above. It is through the various signals or textual clues 
and through point of view that we can identify the type of narrative mode employed in a certain text. Therefore, the sample analysis of narrative mode in the short stories, "The Tell- Tale Heart" and "God Sees the Truth, But Waits" goes independently as follows.

\subsection{The Analysis of Narrative Mode in "God Sees the Truth, but Waits"}

\subsubsection{The Telling Features of Narrative Mode in "God Sees the Truth, but Waits"}

Regarding the telling feature of the narrative mode in the story underdiscussion, the narrator is an omniscient third person narrator who knows not only the characters do and say, but also what the characters think and like to do or say. The short story underdiscussion is narrated both in a scenic and telling mode of narration. Therefore, we can have the following textual extracts as sample features of telling narrative mode employed in the short story of my point of discussion.

Aksionov was a handsome, fair-haired, curly-headed fellow, full of fun, and very fond of singing. When quite a young man he had been given to drink, and was riotous when he had had too much; but after he married he gave up drinking..., P.1. Here in the extract above we can understand the narrator's feeling or attitude in expressing the character's/Aksionov's trait as the words and expressions: 'handsome', 'fair-haired', 'full of fun', 'fond of singing' and others reveal. Therefore, this textual clue can be taken as an exemplary evidence for the utilization of telling mode of narration in the narration process of the story underdiscussion.

In addition we can have a look at of the following textual extract as a telling mode of narration.

It was not Aksionov's habit to sleep late, and, wishing to travel while it was still cool, he aroused his driver before dawn, and told him to put in the horses..., P.1.

The expression, 'It was not Aksionov's habit to sleep late, and, wishing to travel while it was still cool, in the extract above indicates us the narrator's skill of commentary on the personal traits or habits of the character, Aksionov sothat the extract is an indicator of telling mode of narration.

Plus, we can look the following extract under the discussion of telling mode of narration in the story underdiscussion. ....all the twenty-six years of his prison life, and his premature old age. The thought of it all made him so wretched that he was ready to kill himself, P. 6.

The expression, 'The thought of it all made him so wretched that he was ready to kill himself', in the extract tells us the narrator's skill of judgment that the character Aksionov is ready /coming to kill himself because of the experiences he had suffered, and it is or judgment is the highest indicator of a telling narrative mode in the narration process.

Moreover, we can add the following extract as an indicator of a telling mode of narrative reflected as the narrator's judgment in the narration process of the short story underdiscussion.

A fortnight passed in this way. Aksionov could not sleep at night, and was so miserable that he did not know what to do, P. 6. Here, the expression. '...was so miserable...' is telling us the narrator's feeling that the situation that the central character, Aksionov went through was miserable so that the narrator pities the character; and it is one manifestation of a narration process in which telling narrative mode is employed.

In short the extracts highlighted above are some of the extracts which enable us the utilization of telling mode of narration in the narrative process of the short story, "God Sees the Truth, but Waits" which is a point of discussion in this paper. The next section of this paper presents us with the showing mode of narration of the short story mentioned above.

4.1.2 The Showing Features of Narrative Mode in "God Sees the Truth, but Waits"

The showing mode of narrative in the short story underdiscussion is mostly experience in the narrator's skill of representing the characters direct discourse. For example, the following direct characters' speeches are exemplary extracts which show this case.

One summer Aksionov was going to the Nizhny Fair, and as he bade good-bye to his family, his wife said to him, "Ivan Dmitrich, do not start to-day; I have had a bad dream about you."

Aksionov laughed, and said, "You are afraid that when I get to the fair I shall go on a spree."

His wife replied: "I do not know what I am afraid of; all I know is that I had a bad dream. I dreamt you returned from the town, and when you took off your cap I saw that your hair was quite grey."

Aksionov laughed. "That's a lucky sign," said he. "See if I don't sell out all my goods, and bring you some presents from the fair." P.1. In the extract above, except the first line in which the narrator introduces the setting of the dialogue 
between the central character of the story, Aksionov and his wife, all the sentences are the direct speeches of the characters through which the narrator takes us into the minds and hearts of the characters sothat we are nearer to the characters; and the intermediacy of the narrator is minimal; in turn, which shows us the scenic or showing presentation of the narration process. Plus, in the extract above, we have a foreshadowing one feature of scenic presentation in the form of 'dream' that the wife of Aksionov dreamt as the expression, wife said to him, "Ivan Dmitrich, do not start to-day; I have had a bad dream about you." indicates. Here, though Aksionov rejects his wife's advice, we can intellectually/technically guess that if he doesn't accept her advice, he will experience some sort of bad condition; and that is what Aksionov has got the development of the story. Therefore, it/foreshadowing in the form of dream in this story is one feature of scenic presentation of narration. This is not the only foreshadowing used in the story; we have another example in the story underdiscussion. Forexample, the expression in the story, "It seems that only God can know the truth; it is to Him alone we must appeal, and from Him alone expect mercy." reveals the expression uttered by the central character of the story, Aksionov when everybody including his wife is hesitating to accept the truth behind Aksionov; and even the title of the short story, "God Sees the Truth, but Waits" implies that it is only God reveals and knows the truth the case behind Aksionov where he has been accused of the case which he doesn't know; and it has been revealed after twenty six years of prison. Therefore it is an exemplary foreshadowing for the scenic presentation of the story.

In addition we can have much more direct speeches used in the story; and some are listed below as extracts taken from the actual story.

Then his wife said, "It was not for nothing I dreamt your hair had turned grey. You remember? You should not have started that day." And passing her fingers through his hair, she said: "Vanya dearest, tell your wife the truth; was it not you who did it?" P.3.

"Where are you from?" asked some one.

"From Vladimir. My family is of that town. My name is Makar, and they also call me Semyonich."

Aksionov raised his head and said: "Tell me, Semyonich, do you know anything of the merchants Aksionov of Vladimir? Are they still alive?"

"Know them? Of course I do. The Aksionovs are rich, though their father is in Siberia: a sinner like ourselves, it seems! As for you, Gran'dad, how did you come here?" P.5.

Plus, we can add the following vast extract as an exemplary extract for the scenic presentation of the story underdiscussion.

When Aksionov heard these words, he felt sure this was the man who had killed the merchant. He rose and went away. All that night Aksionov lay awake. He felt terribly unhappy, and all sorts of images rose in his mind. There was the image of his wife as she was when he parted from her to go to the fair. He saw her as if she were present; her face and her eyes rose before him; he heard her speak and laugh. Then he saw his children, quite little, as they: were at that time: one with a little cloak on, another at his mother's breast. And then he remembered himself as he used to be-young and merry. He remembered how he sat playing the guitar in the porch of the inn where he was arrested, and how free from care he had been. He saw, in his mind, the place where he was flogged, the executioner, and the people standing around; the chains, the convicts..., P.6.

Here, the description above is a description made by the narrator of the story from the point of view/view pint of the character of the story, Aksionov in a scenic/showing mode of narrative. So, though the extract is made of an extensive description which seems to be a telling mode of narration, it is not a telling narration; rather, it is a scenic presentation because of its feature of creating an image from the view point of the character of the story. Therefore, any description of something in the narration process should not be taken as a marking feature of telling narrative mode; rather, from what view point the description is made should be considered as a central point of argument. In other words, if a description is made from the character's view point, the narrative mode is inclined to be a scenic/showing mode of narrative as long as the description takes us nearer to see things from the minds and hearts of the character of the story.

\subsection{The Analysis of Narrative Mode in "The Tell- Tale Heart"}

\subsubsection{The Telling Features of Narrative Mode in "The Tell- Tale Heart”}

Regarding the telling feature of the narrative mode in the story underdiscussion, the narrator is the first person narrator who tells us his own experience. The narrator in this case is the character of the story since the narrator is part and parcel of the experiences/events in story line. The short story, "The Tell- Tale Hear", the narrator tells us the first person narrator, the character of the story his own action that he killed his old neighbour because of his hate to 
the colour of eye what the neighbour has not because of other rigorous factor; and the narrator in this story is the character to the narrated story sothat there is not authorial involvement in the narration process. It is the narration in which narration is made through absolute first person narrator. It is only through one/the central character of the story the narration is made. We have only few direct discourses/ direct speeches and direct thoughts of characters' like:

... when my thumb slipped upon the tin fastening, and the old man sprang up in bed, crying out --"Who's there?", p. 1. He had been saying to himself --"It is nothing but the wind in the chimney --it is only a mouse crossing the floor," or "It is merely a cricket which has made a single chirp." P.2.

Even these direct discourses are not indicators of the authorial involvement of narration for one thing; these are direct discourses which show the direct utterances and thoughts of characters in the story. Plus, these direct discourses in the short story underdiscussion are quoted by the central character about the other character, not by the narrator as a representative of the author.

All in all, we couldn't find any signal which shows us the presence of the authorial involvement in the whole narration process of the short story underdiscussion. Thus, the short story doesn't have any authorial involvement features of narrative mode. As it has been indicated above, we couldn't find any word of the author since the narrator is fully the character of the story in the whole text of the story; all the words are the words of the characters of the story.

\subsubsection{The Showing Features of Narrative Mode in "The Tell- Tale Heart"}

The narrator begins the short story ingeneral and the first page in particular with the character's stream of consciousness or interior monologue that implies to know what is going on the character's mind as:

TRUE! --nervous --very, very dreadfully nervous I had been and am; but why will you say that I am mad? The disease had sharpened my senses --not destroyed --not dulled them. Above all was the sense of hearing acute. I heard all things in the heaven and in the earth. I heard many things in hell. How, then, am I mad? Hearken! and observe how healthily --how calmly I can tell you the whole story, p.1.

This is a showing mode of narration which brings us to the mind and heart of the central character in stream of consciousness in the form of apostrophe in which the character seems to address his idea to someone else where there is not any one to listen/hear him. In addition the stream of consciousness of the character in which the conflict is introduced advances in the following way:

It is impossible to say how first the idea entered my brain; but once conceived, it haunted me day and night. Object there was none. Passion there was none. I loved the old man. He had never wronged me. He had never given me insult. For his gold I had no desire. I think it was his eye! yes, it was this! He had the eye of a vulture a pale blue eye, with a film over it. Whenever it fell upon me, my blood ran cold; and so by degrees -very gradually --I made up my mind to take the life of the old man, and thus rid myself of the eye forever... Now this is the point. You fancy me mad. Madmen know nothing. But you should have seen me. You should have seen how wisely I proceeded --with what caution... p.1.

Moreover, the stream of consciousness or the interior monologue has reached in its tensed mood in the end part of the story when the police officers are coming to disclose the matter, experienced by the central character as it is revealed in the textual extract below.

No doubt I now grew very pale; --but I talked more fluently, and with a heightened voice. Yet the sound increased --and what could I do? It was a low, dull, quick sound --much such a sound as a watch makes when enveloped in cotton... Why would they not be gone? I paced the floor to and fro with heavy strides, as if excited to fury by the observations of the men --but the noise steadily increased. Oh God! What could I do? ... Was it possible they heard not? Almighty God! --no, no! They heard! --they suspected! -they knew! --they were making a mockery of my horror!-this I thought, and this I think, p.3.

These are not the only textual clues which show us the narrator takes the authorial involvement is far from the narration process in which we can directly approach the characters like drama in a scenic manner. For example, we can have the following extract which shows as the figural aspect of the narration process.

Upon the eighth night I was more than usually cautious in opening the door. A watch's minute hand moves more quickly than did mine. Never before that night had I felt the extent of my own powers--of my sagacity. I could scarcely contain my feelings of triumph. To think that there I was, opening the door, little by little, and he not even to dream of my secret deeds or thoughts. I fairly chuckled at the idea; and perhaps he heard me; for he moved on 
the bed suddenly, as if startled. Now you may think that I drew back --but no. His room was as black as pitch with the thick darkness, (for the shutters were close fastened, through fear of robbers,) and so I knew that he could not see the opening of the door, and I kept pushing it on steadily, steadily, P.1.

As a first person narrator and a single story line due to the nature of short story, the narrator has a problem of consideration in time and space or a problem of moving here and there so that there will be a gap in the mind style of the narrator so that he/she will consider the world only from his/her perspective. For example, the expression, when the entire world slept, implies that the narrator's knowledge gap due to the reasons mentioned above. Here, the narrator is considering as the entire world has a night time. Here, is the extract quoted.

Presently I heard a slight groan, and I knew it was the groan of mortal terror. It was not a groan of pain or of grief --oh, no! -it was the low stifled sound that arises from the bottom of the soul when overcharged with awe. I knew the sound well. Many a night, just at midnight, when the entire world slept, it has welled up from my own bosom, deepening, with its dreadful echo, the terrors that distracted me. I say I knew it well, P.1.

All in all, as it has been indicated above, the short story, "Tell-Tale Heart" is narrated in showing mode of narration it might be due to the content/story entertained. The story is all about an individual's confession to his guilty of killing an old man due to not rigorous conflict, it is simply due to the unpleasant colour what an old man has as it has been expressed in the extract below.

It is impossible to say how first the idea entered my brain; but once conceived, it haunted me day and night. Object there was none. Passion there was none. I loved the old man. He had never wronged me. He had never given me insult. For his gold I had no desire. I think it was his eye! yes, it was this! He had the eye of a vulture a pale blue eye, with a film over it. Whenever it fell upon me, my blood ran cold; and so by degrees-very gradually --I made up my mind to take the life of the old man, p.1.

Therefore, it might be due to this reason that the narration is inclined to be showing mode of narration since authorial involvement is nearly not existed so that the central character can keep this unusual experience personal or secret though he is not able to keep it secret as the final part of the story revealed this secret.

In addition, as the narrator is not directly involved as an authorial involvement in the narration of the story, all the issues entertained in the story are narrated from the point of view of the characters sothat the narration mode employed in the narration process is a almost nearly to be showing/scenic narrative mode.

Plus, the narration uses the title as a foreshadowing to the result and probably the theme of the story. Thus, the title, "The Tell-Tale Heart" the world "Tell" is used as a noun and it may imply that it is the story, told by the hear or it is the story/ tale belongs to the heart; and it is the heart of the dead man supposed to knock the ear and general feeling of the killer which leads him to reveal the case, expected to be secret to him. In turn foreshadowing is one feature of showing/ scenic narrative mode.

\section{Conclusion}

So far, the analysis of the two short stories written by two different authors presented or narrated in different ways. The former short story, "God Sees the Truth, but Waits" by Tolstoy is narrated both in a scenic and telling mode of narration in which authorial involvement is highly seen in some parts of the story; whereas, the second short story, "The Tell- Tale Heart" by Poe is narrated fully in a scenic mode of narration where the authorial involvement is highly absent. Therefore, technique or narrative mode is personal so that we can conclude as there is not one universally accepted way of narration used by different writers for the narration/presentation of one issue probably even by a single writer in different literary texts as stylisticians, like Lech and short say style is the man .

In addition mostly, description is taken as the signal which shows us the telling mode of narration. However, the short story, "The Tell- Tale Heart" there is the description which can be seen as a signal of a showing/scenic mode of narration; and it might be true because of the nature of the description. The description made is from the point of view of the character, not from the point of view of the narrator where there is not authorial involvement in the description process.

\section{References}

Alem, S. (2011). Narrative mode on selected Aimattadoo's short stories. Mekelle University.

Bale, M. (1997). Narratology: Introduction to the theory of Narratives(3rd ed.). England: Ashagate Publishing 
Company.

Booth, W. (1982). The rhetoric of Fiction. Chicago University: Chicago University Press.

Chatman, S. (1978). Story and Discourse. Narrative Structure in Fiction and Film. London: Cornell University presss.

Currie, G. (2010). Narrative and Narrators: A Philosophy of Stories. Oxford Press: New York. http://dx.doi.org/10.1093/acprof:oso/9780199282609.001.0001

Demeke, T. (2014). Narrative strategies in selected Amharic novels from 2000 until 2010. UNISA.

Flundernik, M. (2009). An Introduction to Narratology. Taylor and Francis e-library.

Gentte, G. (1980). Narrative Discourse. Oxford: Blackwell.

Jahn, M. (2005). Narratology: A Guide to the theory of Narrative. Cologne University.

Jan Chr. (2013). The Living document as Handbook of Narratology. Hamburg University;

Julia, Chai. (2003). Narratives and Story-Telling. Hamburg University

Leech, G., \& Short, M. (1981). Style in Fiction: A Linguistic Introduction to English Fictional Prose. New York: Longman.

Melkie, A. (2011). Narrative mode on Achebe's novel: A Man of the People. Mekelle University.

Mitchell, M., \& Edugo, M. (2003). A Review of Narrative Methodology. Hamburg University. http://dx.doi.org/10.1037/e426492005-001

Remmon Kenan, Shi. (1983). Narrative Fiction: Contemporary Poetic. London and New York.

Richardson, B. (2006). Unnatural Voices: Extreme Narration in Modern and Contemporary Fiction. The Ohilo State University.

Riessman Catherine, K. (2008). Narrative Methods for the Human Sciences, CA. USA: SAGE Publications.

Short, M. (1996). Exploring the Language of Poems, Plays and Prose. New York: Longman.

Stanzel Franz, K. (1971). Narrative Situation in the Novel. London: Indian University Press.

Toolan, M. (2001). Narrative: A Critical Linguistics Introduction(2nd ed.). London: Routledge. 